\title{
Wielka Wojna jako temat gier wideo. Wyzwania dla edurozrywki w Valiant Hearts i Battlefield 1
}

The Great War as a theme of video games. Challenges for edutainment in "Valiant Hearts" and "Battlefield 1"

\section{Łukasz Czajka}

Uniwersytet im. Adama Mickiewicza w Poznaniu lukcza@amu.edu.pl | ORCID: 0000-0001-9456-8753

\begin{abstract}
The main task of the paper is to analyze selected video games dedicated to the subject of the World War I. For the purpose of in-depth comparative analysis, two games are confronted with each other: Valiant Hearts and Battlefield 1. Both games are compared in terms of their potential use in entertainment-education (edutainment). The presented interpretations serve also to formulate some potential challenges for video games with aspirations to become tools for supporting the traditional education process about the history of the Great War.
\end{abstract}

Keywords: World War I, war video games, edutainment 



\section{Wstęp}

Dwie plagi wyniszczały żołnierzy Wielkiej Wojny. Obie zostały przedstawione w filmie dokumentalnym I młodzi pozostaną, który w całości składa się ze świadectw brytyjskich weteranów komentujących koloryzowane nagrania życia w okopach frontu zachodniego. Pierwszą z owych plag był koszmar pozycyjnej wojny materiałowej, toczonej w wielokilometrowych okopach, w których żołnierze tonęli w błocie, byli zjadani żywcem przez szczury i pchły, a śmierć spadała na nich z nieba w postaci ostrzału artyleryjskiego. W zdepersonalizowanej wojnie żołnierze utracili status wojowników, stając się jedynie zasobami ludzkimi w statystykach ekonomii militarnej. Drugą plagą była udręka nudy towarzyszącej długim okresom przebywania na tyłach frontu w oczekiwaniu na podjęcie działań wojennych. Z bezczynności zrodziła się potrzeba zapełnienia czasu rożnego rodzaju grami. Przede wszystkim były to gry sportowe, takie jak walki bokserskie lub mecze piłki nożnej, ale także rozmaite gry karciane. Widok pierwszych kamer wzbudzał wielkie zainteresowanie wśród żołnierzy, którzy chętnie pozowali do nagrywanych scen. Zapewne nie przypuszczali, że kiedyś ich historia zostanie opowiedziana poprzez wykorzystanie interaktywnego medium, jakim są gry wideo.

Zadaniem artykułu jest przedstawienie analizy wybranych gier o I wojnie światowej ocenianych pod względem możliwości ich zastosowania jako pomocniczego materiału edukacyjnego. W pogłębionej analizie porównawczej zestawione ze sobą będą edukacyjne potencjały dwóch gier: Valiant Hearts i Battlefield 1. Obie wpisane zostaną w ideę edurozrywki. Ich wspólne omówienie służyć ma także prezentacji głównych wyzwań, przed którymi stoją popularne gry wojenne chcące aspirować do miana pomocy dydaktycznej.

\section{Przegląd wybranych gier o Wielkiej Wojnie}

Wielka Wojna nie należy do najpopularniejszych tematów komercyjnych gier wojennych (Chapman, 2016), a niedawny wzrost liczby premier i wzmożone zainteresowanie grami o niej związane były z setnymi rocznicami rozpoczęcia i zakończenia tego konfliktu. Wśród dostępnych 
pozycji dominują gry strategiczne, symulatory walk powietrznych i morskich, pierwszoosobowe strzelanki oraz gry przygodowe.

Za pierwszą grę o Wielkiej Wojnie uchodzi wydana w 1980 roku gra automatowa Red Baron. Wykorzystuje ona grafikę wektorową i jest prostą symulacją walk lotniczych. Tytuł nawiązuje do pseudonimu słynnego pilota, którym był as niemieckiego lotnictwa Manfred von Richthofen. Powstawały także gry próbujące symulować bitwy morskie - przykładem służy 1914 Shells of Fury, symulator okrętów podwodnych. Dotyczy kontrowersyjnego tematu, gdyż w okresie Wielkiej Wojny ataki podwodne uchodziły za niehonorowe akty barbarzyńskiego terroru (Chwalba, 2014, s. 472-473). Gry symulujące walki morskie były bardzo skomplikowane i wymagały czasochłonnego opanowania wielu zasad wirtualnego sterowania okrętami, przez co stawały się mało przystępne dla odbiorców. Symulatory lotnictwa i walk morskich wykraczały poza rozpowszechnione przedstawienia wojny okopowej i zwracały uwagę na mniej znane oblicze toczonych walk oraz na wykorzystanie w nich nowych zdobyczy techniki.

Wśród gier strategicznych dominują klasyczne strategie czasu rzeczywistego, których odmianą są grand strategy games (wielkie/globalne gry strategiczne). W grach tego typu kampanie militarne uzupełniane są zarządzaniem gospodarką i uprawianiem dyplomacji. Jedną z najnowszych gier strategicznych o Wielkiej Wojnie jest przeglądarkowa Supremacy 1914. Wzbudziła ona w Polsce kontrowersje, gdyż w jednym z materiałów promocyjnych jej twórcy zadawali pytanie o powody, dla których Polacy wywołali wojnę (Sieja, 2019). Natomiast ciekawą inicjatywą fanowską jest Great War Mod, czyli modyfikacja popularnej gry Napoleon Total War. Kłopot w rozgrywkach tego typu stanowi pozycyjny charakter działań na froncie zachodnim, gdyż wierne odwzorowanie ich przebiegu mogłoby zaszkodzić grywalności. Dlatego twórcy decydują się na dynamizację walk toczonych na wirtualnym polu bitwy i na upodobnienie ich do starć wojny ruchomej z frontu wschodniego.

Stosunkowo niewiele gier o Wielkiej Wojnie należy do kategorii first person shooter. Wśród nich można wskazać na polską NecroVision, której akcja toczy się w okresie I wojny światowej, lecz jest to gra z gatunku fantastyki wojennej, gdyż w okopach można spotkać rożnego rodzaju potwory $\mathrm{i}$ istoty nadprzyrodzone. Większą dbałość o realia historyczne 
wykazuje rozpoznawalna na całym świecie gra Battlefield 1 (dalej jako BF1), oferująca fabularną kampanię jednoosobową oraz bardzo popularny tryb wieloosobowy, wspierany licznymi dodatkami rozbudowującymi możliwości pojedynków sieciowych. Niektóre gry rezygnują z jednoosobowego trybu fabularnego i całkowicie skupiają się na rozgrywce toczonej przez internet. Tu za przykład może posłużyć Verdun ${ }^{1}$, jak również niewydana jeszcze Beyond the Wire.

Wśród gier opowiadających o skomplikowanych losach żołnierzy Wielkiej Wojny nie zabrakło także produkcji przygodowych. Jest wśród nich wyróżniająca się dużym potencjałem edukacyjnym dwuwymiarowa gra przygodowa Valiant Hearts: The Great War (dalej jako vH), w szacie graficznej odwołująca się do stylistyki komiksu. Warto podkreślić, że jej twórcy nie chcieli stworzyć gry wojennej przepełnionej efektownymi bitwami, lecz interaktywną opowieść o losach zwykłych ludzi podczas wojennej zawieruchy (Kempshall, 2015a, s. 667). Kolejną grę przygodową o tym tragicznym okresie w dziejach świata stanowi 11-11 Memories Retold, której rozbudowana fabuła opowiada wojenne historie kanadyjskiego fotografa i niemieckiego inżyniera. Także w tym przypadku grę wyróżnia oprawa graficzna, gdyż jej inspiracją były obrazy impresjonistyczne. Natomiast najnowszą grą z tego gatunku jest Within Whispers: The Fall mówiąca o losach sanitariuszki poszukującej zaginionego brata. Bohaterka ma nadprzyrodzone zdolności - potrafi komunikować się z duchami ofiar wojny.

\section{Czym jest edurozrywka?}

Edurozrywka (edutainment) jest hybrydowym stylem nauczania łączącym w sobie elementy edukacji i rozrywki (Aksakal, 2015, s.1232-1233; Okan, 2003, s. 255-256; Peña-Miguel, Sedano, 2014, s. 230; Skibińska, 2010, s. 62). W jego ramach zabawa interaktywnym światem gry jest środkiem uatrak-

1 Grę Verdun wyróżnia dbałość o realizm pola walki (zginąć można już od jednego trafienia) oraz opcja upamiętnienia bożonarodzeniowego rozejmu, który miał miejsce na froncie zachodnim w 1914 roku. Gracze w czasie tego rozejmu zamiast w walkach mają szansę uczestniczyć w zabawie obrzucania się śnieżkami lub grze w piłkę. Zdarza się także, iż 11 listopada społeczność graczy zawiesza wirtualne walki, aby w ten sposób upamiętnić rocznicę zakończenia wojny (Kempshall, 2019). 
cyjniania procesu edukacyjnego. Gra uczy, pozwalając na popełnianie błędów (porażki w trakcie jej przechodzenia), oraz przekazuje treści, wykorzystując różne media (animacje 3D, utwory muzyczne, grafikę inspirowaną komiksem lub malarstwem, twórczość epistolarną).

Edurozrywka to bardzo pojemna idea, pod której sztandarem realizowane bywają przedsięwzięcia rożnego typu. Przykładem edurozrywki może być inscenizacja bitwy pod Grunwaldem lub czytanie performatywne Obrony Sokratesa. W formułę edurozrywki wpisywałoby się także niestandardowe wykorzystanie tradycyjnych zabawek, takich jak klocki Lego, w ramach projektu Lego-Logos służące np. do zrekonstruowania wnętrza Platońskiej jaskini. Popularnym edurozrywkowym programem telewizyjnym jest słynna Ulica Sezamkowa, w której Liczyhrabia uczy liczyć przy pomocy zabawnych piosenek. Jednakże do najlepszych programów tego typu należy pamiętny serial animowany Było sobie życie, przekazujący podstawowe informacje o funkcjonowaniu ludzkiego organizmu poprzez fabularyzowaną opowieść o życiu krwinek, komórek i wirusów.

Wymienione przykłady unaoczniają, że upowszechnianie się edurozrywki można powiązać ze wzrostem znaczenia dzieł kultury popularnej, wywierających coraz większy wpływ na kształtowanie postaw i światopoglądów ludzi z wielu współczesnych społeczeństw. Magdalena Piechota nie wyklucza, iż opisany przez nią związek edurozrywki i kultury popularnej będzie prowadzić do komercjalizacji edukacji, którą trzeba atrakcyjnie opakować, aby stała się pożądaną usługą w świecie coraz mocniej formowanym przez popkulturową rozrywkę (Piechota, 2010, s. 233-234).

Jeśli chodzi o gry wideo wpisujące się w jakimś stopniu w formułę edurozrywki, to wskazać można na ich dwa typy (Tang, Hanneghan, El Rhalibi, 2009, s. 4-6). Pierwszym są gry specjalnie projektowane dla szkół lub dla potrzeb szkoleniowych. Pod tę kategorię podpadałyby zarówno rozbudowane gry poważne (serious games), jak i proste aplikacje do nauki języków obcych. Hipotetycznym przykładem mogłaby być wirtualna wersja znanego teleturnieju Milionerzy, w której pytania dotyczyłyby materiału przerabianego w trakcie wybranego wykładu akademickiego. Realną egzemplifikacją jest dostępna na stronie Kanadyjskiego Muzeum Wojny gra Over the Top. W swej formie przypomina książki paragrafowe i polega na przeglądaniu kolejnych slajdów opowiadających o wojennych losach żołnierzy. Przebieg 
tych losów można wyznaczać, podejmując samodzielnie decyzje o kierunku rozwoju ścieżki fabularnej. Zaangażowanie i osobisty odbiór gry ulegają wzmocnieniu dzięki temu, że na jej początku zostajemy poproszeni o podanie własnego imienia oraz imienia najlepszego przyjaciela, co niejako stawia nas na miejscu żołnierzy, których koleje życia śledzimy w grze. Drugą kategorią są popularne gry rozrywkowe dostępne powszechnie w sklepach na całym świecie. Wśród nich można dokonać jeszcze dodatkowego podziału na takie gry, które zostały stworzone z wyraźną intencją edukacyjną (vH), oraz takie, w których aspekt edukacyjny jest dodatkiem wynikającym z umieszczenia przebiegu rozgrywki w kontekście jakiegoś wydarzenia historycznego (BF1).

Plusem edurozrywki może być atrakcyjna forma, przyciągająca uwagę i angażująca w zgłębianie danego tematu ${ }^{2}$. Zaletami będą też sprzyjanie samokształceniu oraz wytworzenie wewnętrznej motywacji do uczenia się dzięki zaangażowaniu emocjonalnemu w proces pozyskiwania wiedzy. Alice Mitchell i Carol Savill-Smith, autorki raportu o wykorzystaniu gier w procesie dydaktycznym, dowodzą, że towarzysząca grom zabawa czyni proces edukacji przyjemnym, pojawiające się w nich coraz trudniejsze wyzwania wzbudzają motywację do opanowania nowych treści i umiejętności (takich jak kreatywne rozwiązywanie problemów), interaktywność pozwala na wyjście poza bierny odbiór przekazywanej wiedzy, a dodanie historii fabularnych zwiększa zaangażowanie poprzez wykorzystanie emocji wzbudzanych przy okazji przeżywania losów postaci. Gry wieloosobowe dają także szansę na doświadczenie ekscytacji wynikającej ze współzawodnictwa z innymi, gdyż w grach na bieżąco wyświetlają się informacje zwrotne o postępach oraz wyniki, dostępne do porównań (Mitchell, Savill-Smith, 2004, s. 17-18).

Jednakże wykorzystanie formuły edurozrywki ma także swoje ograniczenia. Atrakcyjna forma rozrywkowa może przesłonić aspekt edukacyjny, a nadmiar edukacji rozrywkowej - zniechęcić do bardziej tradycyjnych form nauczania. Zwrócić należy także uwagę na to, że edurozrywka

2 Przykładem takiego zwiększonego zainteresowania poszukiwaniem wiedzy naukowej, którego źródłem jest kontakt z dziełem kultury popularnej zawierającym treści historyczne, jest youtuberski kanał edukacyjny The Great War, który zanotował zauważalny wzrost liczby subskrypcji już po premierze zwiastuna BF1 (Crocker, 2017, s. 30-33; The Great War, 2016). 
jest dobrą formułą do przekazywania jedynie podstawowych informacji, gdyż tylko taki prosty przekaz daje się skutecznie połączyć z niewymagającą rozrywką. Dlatego powinna być ona traktowana jako dodatek do bardziej tradycyjnych form edukacji i uzupełniana bezpośrednią współpracą z nauczycielami lub lekturą obszernych materiałów źródłowych.

\section{Analiza porównawcza gier Valiant Hearts i Battlefield 1}

Obie porównywane gry miały swe premiery w podobnym czasie ( $\mathrm{vH}$ w roku 2014, BF1 w 2016), związanym z obchodami setnych rocznic rozpoczęcia i zakończenia I wojny światowej. Obie zyskały uznanie odbiorców, a ponadto vH zdobyła kilka prestiżowych nagród (w tym dwie nagrody BAFTA w kategoriach „Artistic Achievement” oraz „Original Property”), a BF1 otrzymała pozytywne oceny w branżowych mediach oraz osiągnęła komercyjny sukces, gdyż sprzedała się w milionach egzemplarzy. Popularność tych produkcji sprawia, że mogą one być brane pod uwagę jako potencjalne źródła wiedzy o Wielkiej Wojnie.

Przeprowadzona analiza porównawcza dotyczy trzech kwestii. Po pierwsze: czy gry zawierają w sobie treści edukacyjne dotyczące wydarzeń I wojny światowej? Po drugie: czy treści edukacyjne są dobrze wkomponowane w przebieg gry i nie zakłócają jej wymiaru ludycznego? Po trzecie: czy gry zawierają jakieś kontrowersyjne komponenty, będące przeszkodą dla ich polecenia jako materiałów wspomagających edukację o Wielkiej Wojnie?

VH obejmuje bardzo dużo elementów o wartości edukacyjnej. Co najważniejsze, nie dotyczą one informacji z zakresu jedynie historii wojskowości i przebiegu toczonych walk, ale także społecznego, ekonomicznego i kulturowo-religijnego kontekstu wojny. Wiadomości faktograficzne pojawiają się przy okazji opisów zbieranych przedmiotów codziennego użytku. Do każdej misji dodano także zdjęcia historyczne z komentarzem zawierającym szerszy kontekst wydarzeń, w których możemy uczestniczyć. Warto podkreślić, że nierzadko nie są to informacje powszechnie znane. Przykładem może być opis amerykańskiej maszynki do golenia, której używanie było bardziej bezpieczne niż stosowanie brzytwy, a samo golenie okazywało się bardzo ważne, gdyż przyczyniało się do 
zwiększenia skuteczności maski przeciwgazowej. Oprócz tego w grze znajdziemy także liczne świadectwa osobistych doświadczeń wojennych zwykłych ludzi, które przekazywane są za pośrednictwem listów wymienianych pomiędzy bohaterami gry. W ten sposób jej twórcy, wzorując się na prawdziwych listach wojennych, opowiadają historię wojny poprzez indywidualne ludzkie losy ${ }^{3}$. Wielość różnorodnych treści edukacyjnych pozwala na postrzeganie gry jako ,interaktywnego muzeum” (Anderson, 2019) lub „multimedialnej encyklopedii” (Żmuda, 2016, s. 601). Wspomniane elementy edukacyjne są bardzo dobrze wkomponowane w przebieg rozgrywki, nie wywołując efektu emersji. vH często przypomina nam o pojawieniu się nowych treści edukacyjnych, ale nie zmusza do korzystania z nich. Pomaga także w przebrnięciu przez kolejne etapy, podsyłając gołębiem pocztowym niezbędne wskazówki. Wiarygodność przekazywanych informacji oparta jest na współpracy z państwowymi instytucjami, takimi jak Mission Centenaire 14-18, oraz z twórcami popularnego filmu dokumentalnego Apokalipsa: I wojna światowa. W kontekście edukacji rozrywkowej duży plus gry stanowi to, że choć pokazuje ona w przejmujący sposób tragizm śmierci ofiar wojny ${ }^{4}$, to jednak sama nie polega na zabijaniu, a jej bohaterowie często nie noszą nawet broni. Ograniczają się do ogłuszania przeciwników, którym nierzadko okazują

3 Historia Emile’a przedstawia losy dojrzałego francuskiego żołnierza, który chce chronić swoją rodzinę oraz młodszych towarzyszy broni przed grożącą im śmiercią. Podejmując się ich obrony, poświęca swoje własne życie. Karl jest niemieckim zięciem Emile’a. Zostaje oderwany od swojej francuskiej rodziny przez wybuch światowego konfliktu. Jego historia ukazuje dramat rodzin rozdzielonych przez konflikt. W wojnie toczonej przez Karla nie chodzi o zwycięstwo nad wrogiem, lecz o przetrwanie i powrót do domu. Freddie to Afroamerykanin, który jako ochotnik dołączył do toczonej w Europie wojny. Nie uczynił tego ze względów ideologicznych lub patriotycznych, lecz z powodu osobistego poszukiwania zemsty za śmierć żony. Jego dzieje są także historią udziału w wojnie żołnierzy reprezentujących mniejszości etniczne (w grze pojawiają się również oddziały z Indii i Senegalu). Natomiast historia pielęgniarki Anny (poszukującej porwanego ojca) stanowi przykład wytrwałej służby i odważnego niesienia pomocy ofiarom obu stron konfliktu zbrojnego. Dla Anny każdy uratowany jest jej osobistym zwycięstwem nad wojną. Zróżnicowanie zawartych w grze narracji pozwala dotrzeć do odbiorców o różnym pochodzeniu, płci lub wieku, a także spojrzeć na wojnę przez pryzmat doświadczeń nie tylko żołnierzy, ale także ludności cywilnej.

4 Przykładem takiej przepełnionej emocjami sceny jest przejmujące pożegnanie i odprowadzenie Emile’a przed pluton egzekucyjny, co nasuwa skojarzenia z filmem Ścieżki chwały (reż. S. Kubrick, USA 1957), w którym ukazano bezsensowne okrucieństwo sądów wojskowych. 
sympatię, gdyż ostatecznym wrogiem wszystkich jest wojna sama w sobie (Kempshall, 2015b, s. 26). To sprawia, że vH polecić można nie tylko studentom, ale i młodzieży szkolnej. Do pełni zrealizowania wymogów edurozrywki brakuje tylko testu sprawdzającego stopień przyswojenia przekazywanej wiedzy, jest to jednak element raczej niewystępujący w popularnych grach komercyjnych.

Aby nie poprzestać wyłącznie na pochwałach, warto dodać jeszcze dwie uwagi krytyczne, które pojawiają się w dyskusjach dotyczących oceny gry. Po pierwsze, wspomniane już unikanie zabijania pozwala skierować produkcję do młodszych odbiorców i nadać jej charakter antyprzemocowy, jednakże jest to nieadekwatne przedstawienie frontowych walk, w których żołnierze rzadko mogli ograniczyć się do ogłuszania swych przeciwników. Po drugie, vH zarzuca się zbytni frankocentryzm oraz przedstawienie strony niemieckiej w zdecydowanie bardziej negatywny sposób, gdyż w roli głównego antagonisty osadzono niemieckiego barona Von Dorfa, który swym wyglądem przypomina niemieckiego feldmarszałka Augusta von Mackensena (History Respawned, 2014). Odpowiadając na te zarzuty, trzeba wszakże podkreślić, że bohaterem pozytywnym, reprezentującym stronę niemiecką, jest Karl, a jednym z najbardziej złowrogich antagonistów - francuski oficer, który przymusza swych żołnierzy do straceńczego szturmu na pozycje wroga, zabijając cofających się kompanów Emile’a.

Potencjał edukacyjny BF1 okazuje się dużo bardziej problematyczny. Fabularna kampania w trybie jednoosobowym zawiera informacje historyczne o I wojnie światowej, pojawiające się w animowanych przerywnikach pomiędzy poszczególnymi misjami oraz w zdobywanych wpisach do wojennych dzienników, obejmujących głównie rozszerzone komentarze do militarnego aspektu wojny. Także w tym przypadku nie są to banalne informacje, gdyż twórcy polemizują np. z powszechnym postrzeganiem sterowców jako maszyn bardzo łatwych do zestrzelenia. Jednakże problem tkwi w tym, że wspomniane wpisy trzeba odblokować, wykonując w trakcie misji dodatkowe zadania. Do takich zadań należy zabicie pięciu wrogów przy pomocy saperki, co gra pokazuje w sposób bardzo realistyczny. Tak więc, aby dotrzeć do dodatkowej treści edukacyjnej, trzeba kilkakrotnie dopuścić się brutalnego mordu. Misji w BF1 nie da się wykonać bez zabijania wrogów; już w trybie jednoosobowym ich uśmiercanie 
staje się czymś powszechnym. Ten tryb wszakże łatwo pominąć i skupić się na dużo bardziej popularnej rozgrywce wieloosobowej. W niej gra również nie jest pozbawiona elementów edukacyjnych (opisy toczonych bitew), ale w dużej mierze sprowadza się do masowego eliminowania przeciwników w celu pozyskiwania punktów niezbędnych do osiągnięcia wysokiej pozycji w rankingach. Dodatkowo realistyczna i momentami bardzo efektowna oprawa graficzna może wywołać wrażenie nadmiernej estetyzacji przemocy i wojennej rzeczywistości, co najbardziej uwidacznia się w dostępnych na platformie YouTube machinimach, czyli animacjach stworzonych na silniku gry. Pewne zastrzeżenia wywołać może także samo ukazanie przebiegu walk. Plusem gry jest prezentacja mniej znanych frontów Wielkiej Wojny, choćby takich jak pustynie Bliskiego Wschodu. Natomiast obiekcje wzbudzi w niektórych zbytnie zdynamizowanie walk czołgów oraz wszechobecność nigdy niezacinających się karabinów maszynowych. Poza tym część z dostępnej broni maszynowej to prototypy, które nie były powszechnie stosowane na wojennych frontach (Quiroga, Filippaki, 2018, s. 198). Odejście od realistycznego ukazania przebiegu toczonych walk zostało jednak wymuszone przez wymogi atrakcyjnej grywalności - w takiej sytuacji aspekt edukacyjny zawsze zostanie poświęcony dla dobra wymiaru rozrywkowego.

Twórcy BF1, zapewne spodziewając się zarzutów o sprowadzanie wojny do poziomu czystej rozrywki, przygotowali prolog, w którym unaoczniają, że wojna nie jest beztroską przygodą. W jego trakcie zostajemy wrzuceni w sam środek wojennego horroru, a na jego końcu czeka nieuchronna śmierć. Misji z prologu nie można zakończyć zwycięstwem, gdyż wszyscy żołnierze, w których się wcielamy, po kolei giną. W tym miejscu warto odnotować, że anglojęzyczny tytuł tej części to Storm of Steel, co można odczytać jako nawiązanie do frontowych dzienników Ernsta Jüngera, noszących ten sam tytuł. Otwiera się tu ciekawy trop interpretacyjny, w prologu gry pozwalający dostrzec przedstawienie Jüngerowskiej idei wojny, w której żołnierz zostaje całkowicie podporządkowany technice i z wojownika przeistacza się w robotnika obsługującego maszyny wojenne (Jünger, 2010, s. 75). Wspomniany prolog bardzo dobrze ukazuje nowe oblicze wojny materiałowej wraz z jej pięcioma demonami: miotaczem ognia, huraganowym ostrzałem artyleryjskim, czołgiem, zeppelinem oraz atakiem gazowym. 
Jeszcze innym aspektem BF1 prowokującym do zadawania pytań jest jej okładka, na której przedstawiony został afroamerykański żołnierz z regimentu Piekielnych Wojowników Harlemu. Żołnierze z tego oddziału występują także w prologu otwierającym grę, a ich obecność nie wynika z chęci zadośćuczynienia współczesnym wymogom polityki tożsamościowej, lecz stanowi adekwatne przedstawienie faktów historycznych. Jednakże największe dyskusje wywołało pokazanie - w materiałach promocyjnych - afrykańskiego żołnierza w mundurze armii niemieckiej. Także w tym przypadku jest to sytuacja, która ma swoje pewne odzwierciedlenie w rzeczywistości historycznej. Co prawda armia niemiecka w walkach w Europie nie mogła wykorzystać żołnierzy wojsk kolonialnych (tak jak Francja w przypadku żołnierzy senegalskich lub Wielka Brytania - tych z indyjskich sił ekspedycyjnych), gdyż blokada morska uniemożliwiała ich przetransportowanie (Chwalba, 2014, s. 271). Jednakże w szeregach wojsk niemieckich służyli pojedynczy żołnierze z Afryki, którzy do Niemiec przybyli najczęściej jeszcze przed wybuchem wojny. Przykładem takiego żołnierza był sierżant Josef Mambo (Quiroga, 2018, s. 190), perkusista w pruskim 3. Pułku Grenadierów, ranny w Rosji i pod Verdun, odznaczony Krzyżem Żelaznym. Wspomniana okładka gry może więc pełnić funkcję sokratejskiego gza, który pobudza do zadawania pytań i do refleksji nad historią kolonializmu ${ }^{5}$.

W tym porównaniu vH wypada zdecydowanie lepiej, w pełni zasługując na miano znakomitego przykładu profesjonalnie realizowanej edukacji rozrywkowej przeznaczonej dla szerokiego grona odbiorców. Natomiast potencjał edukacyjny BF1 okazuje się dużo bardziej problematyczny, gdyż dominacja trybu wieloosobowego sprawia, że w tej produkcji przeważa aspekt czysto rozrywkowy. Dodatkowo wszechobecna w grze brutalna przemoc sprawia, że nadaje się ona raczej jako materiał do omawiania na

5 Ten temat podejmują dwa trójwymiarowe filmy stworzone do oglądania przy wykorzystaniu gogli VR pod tytułem Empire Soldiers (podtytuł pierwszego to A Caribbean Story, a drugiego A South Asian Story). Przedstawiają one losy karaibskich i indyjskich żołnierzy, którzy ruszyli na wojnę, chcąc pokazać swoją lojalność wobec Imperium Brytyjskiego. Narratorzy filmów wspominają, że wszystkich żołnierzy połączyło frontowe braterstwo walki i niedola życia w okopach, jednakże zaraz po wojnie powróciły uprzedzenia rasowe, które ponownie oddzieliły od siebie ludzi drutem kolczastym dyskryminacji. Konkluzja filmów wskazuje, że w historii napisanej przez zwycięzców są jeszcze epizody, które nadal nie zostały powszechnie poznane. 
studiach wyższych, których uczestnicy będą mogli wykorzystać akademicką wiedzę do pogłębionej interpretacji ukrytych w grze tropów oraz krytycznie pochylić się nad jej formą i treścią ${ }^{6}$.

\section{Zakończenie - Wielka Wojna wyzwaniem dla edurozrywki}

Przydatna edukacyjnie gra o Wielkiej Wojnie powinna zawierać w sobie informacje faktograficzne o jej przebiegu i społeczno-kulturowym kontekście, poprzez emocjonalny przekaz wzbudzać empatię wobec jej ofiar i identyfikację z nimi oraz - dzięki wykorzystaniu nowoczesnych technologii - dawać namiastkę okrutnych realiów wojny i jej konsekwencji. Jednakże każda gra tego typu stanie przed przynajmniej trzema wyzwaniami.

Pierwsze z nich wiąże się z niejednoznacznym przebiegiem Wielkiej Wojny, w której trudno wskazać kategorycznie złą stronę konfliktu. To zaś tworzy problem dla skonstruowania narracji gry, gdyż każda z walczących armii może w pewnym stopniu być tą negatywną lub też obie są tej wojny ofiarami ${ }^{7}$. Brak tu moralnej klarowności krucjaty przeciwko złu nazistowskich Niemiec (Chapman, Kempshall, 2017).

Drugim wyzwaniem jest ludyczny charakter gier, postrzegany nieraz jako czynnik deformujący, trywializujący i sprowadzający wojnę do rozrywkowej zabawy (Chapman, 2016). Dotyczy to także szerszego sporu o to, czy gra wideo jest wystarczająco dojrzałym i godnym medium ${ }^{8}$,

6 Zgodnie z Ogólnoeuropejskim Systemem Klasyfikacji Gier (PEGI) BF1 została zaliczona do pozycji przeznaczonych dla osób, które ukończyły 18 lat, co utrudnia jej szerokie wykorzystanie jako pomocy dydaktycznej. Natomiast vH uznano za odpowiednią dla dzieci od 12 lat i to pozwala na jej zastosowanie także w edukacji szkolnej. W tym miejscu warto wspomnieć, że grę This War of Mine zakwalifikowano w Polsce do nieobowiązkowych lektur szkolnych, przeznaczonych jednak tylko dla dorosłych uczniów, gdyż zgodnie z wytycznymi systemu PEGi skierowana jest ona do osób pełnoletnich (Mileszko, 2020). Sądzę, że vH jak najbardziej powinna dołączyć do oficjalnej listy gier wspomagających edukację $\mathrm{z}$ zakresu historii.

7 Jednakże zdecydowana większość dostępnych gier uprzywilejowuje jedną ze stron konfliktu, czyli Ententę. W dalszym ciągu w roli „złych” obsadzani są zwykle żołnierze państw centralnych (History Respawned, 2016).

8 Podobne dyskusje pojawiły się już przy okazji wydania gry Super Columbine Massacre RPG, która przedstawiała wydarzenia związane z masakrą w amerykańskiej szkole 
aby zadawać poważne pytania o prawdę wojennych zbrodni, których traumatyczne wspomnienie nadal pozostaje żywe w zbiorowej pamięci wielu narodów (Filippaki, 2018, s. 177-178).

Natomiast trzecie wyzwanie związane byłoby z globalnym wymiarem Wielkiej Wojny i wielością partykularnych narracji, niedających się w łatwy sposób połączyć w jedną metaopowieść. Gry już teraz mówią o wojnie, przyjmując perspektywy żołnierzy i ludności cywilnej, kobiet i mężczyzn, różnych grup etnicznych, a nawet zwierząt (jednym z bohaterów VH jest pies medyczny Walt, a w BF1 na moment możemy wcielić się w gołębia pocztowego, który był stałym członkiem załóg brytyjskich czołgów). Jednakże w dalszym ciągu pewne punkty widzenia nie pojawiają się; przykładem takiej nieobecnej w grach narracji jest perspektywa polska9. Mogłaby to być opowieść o przymusowym wcieleniu do jednej z zaborczych armii, dezercji i ucieczce do Legionów, wyboistym marszu ku niepodległości i jego zwieńczeniu udziałem w Powstaniu Wielkopolskim u boku Sama Sandiego, kameruńskiego żołnierza polskich oddziałów powstańczych. Jak jednak opowiedzieć pozytywną konkluzję polskiej epopei osobom traktującym 11 listopada jako dzień powagi, zadumy i wspominania ofiary żołnierzy, którym nie dane było zwycięstwo, gdyż skazani zostali na udział w niepotrzebnej i bezsensownej wojnie? Dla Polski skutkiem ubocznym Wielkiej Wojny było odzyskanie niepodległości, co znajduje też swoje odzwierciedlenie w dużo bardziej radosnym

w Columbine. Twórca produkcji bronił się przed licznymi głosami krytyki, stwierdzając, że gry nie powinny służyć wyłącznie rozrywce, gdyż są medium, dzięki któremu można krytycznie komentować ważne wydarzenia społeczne. Dlatego jego gra stanowi próbę pogłębienia namysłu nad źródłami dramatu z Columbine oraz krytyki społeczeństwa, w którym ta zbrodnia mogła się wydarzyć (Ledonne, 2005).

9 Polską perspektywę uwzględniono jedynie w niszowej grze platformowej Ku zwycięstwu, opowiadającej o Powstaniu Wielkopolskim, a stworzonej z okazji setnej rocznicy odzyskania przez Polskę niepodległości. Narracja zaczyna się od historii chłopca, którego ojciec został zabity przez niemieckich żołnierzy. Bohater otrzymuje pomoc od hrabiego Zamoyskiego, a następnie uczestniczy w wydarzeniach związanych $\mathrm{z}$ wybuchem powstania (manifestacja pod Hotelem Bazar, walki o lotnisko Ławica). Gra jest bardzo prosta i krótka (właściwie to raczej minigra), jest także pozbawiona przemocy, a od strony technicznej przypomina proste gry przeglądarkowe. Zawiera sporo treści edukacyjnych, podawanych w dość długich przerywnikach pomiędzy jej kolejnymi etapami. Jej grywalność trzeba ocenić jako niską, a prostota sprawia, że propozycja ta może zainteresować jedynie najmłodszych. Poza tym skierowana została wyłącznie do polskich odbiorców, nie będzie więc dziełem propagującym polskie spojrzenie na zakończenie Wielkiej Wojny poza granicami kraju. 
świętowaniu listopadowej rocznicy, wskazującej na sens polskich zmagań wojennych. Obie historie wzbudzają diametralnie odmienne emocje, obie są prawdziwe, obie zasługują na opowiedzenie. Jedna $\mathrm{z}$ nich doczekała się już swej wirtualnej wersji, druga jeszcze na nią czeka.

\section{Literatura}

Anderson, S. L. (2019). The interactive museum: Video games as history lessons through lore and affective design. E-Learning and Digital Media, 16(3), 177-195. Online: <http://journals.sagepub.com/ doi/abs/10.1177/2042753019834957?icid=int.sj-abstract.similararticles.3\&journalCode=ldma>.

Aksakal, N. (2015). Theoretical View to The Approach of The Edutainment. Procedia - Social and Behavioral Sciences, 186, 1232-1239. Online: <http:// www.sciencedirect.com/science/article/pii/S1877042815023411>.

Crocker, J. (2017). Unorthodox Professors: World War One in Videogames and on YouTube. The Arbutus Review, 8(1), 24-36. Online: <http:// www.researchgate.net/publication/323189816_Unorthodox_Professors_World_War_One_in_Videogames_and_on_YouTube>.

Chapman, A. (2016). It's Hard to Play in the Trenches: World War I, Collective Memory and Videogames. Game Studies, 16(2). Online: <http:// gamestudies.org/1602/articles/chapman>.

Chapman, A., Kempshall, Ch. (16 lutego 2017). Battlefield 1: Can The Great War Be A Great Game? Online: <http://ontologicalgeek.com/battlefield-1-can-the-great-war-be-a-great-game>.

Chwalba, A. (2014). Samobójstwo Europy. Wielka Wojna 1914-1918. Warszawa: Wydawnictwo Literackie.

Filippaki, I. (2018). Great War Games: Notes on Collective Memory, the Adynaton, and Posthumanism. Alicante Journal of English Studies, 31(1), 177-185. Online: <http://rua.ua.es/dspace/bitstream/10045/87227/6/ RAEI_31_11.pdf>.

Jünger, E. (2010). Robotnik. Panowanie i forma bytu - Maksima, Minima (tłum. W. Kunicki). Warszawa: Wydawnictwo Naukowe PWN.

Kempshall, Ch. (2015a). Pixels Lions - The Image of the Soldier in First World War Computer Games. Historical Journal of Film, Radio and 
Television, 35(4), 656-672. Online: <http://www.tandfonline.com/doi/ abs/10.1080/01439685.2015.1096665>.

Kempshall, Ch. (2015b). The First World War in Computer Games. London: Palgrave Macmillan.

Kempshall, Ch. (19 września 2019). Centenary (Computer Games). Online: $<$ http://encyclopedia.1914-1918-online.net/article/centenary_computer_games>.

Ledonne, D. (2005). Artist's Statement: A Meditation on "Super Columbine Massacre RPG!”. Online: <http://www.columbinegame.com/statement. htm>.

Mitchell, A., Savill-Smith, C. (2004). The Use of Computer and Video Games for Learning: A Review of the Literature. London: Learning and Skills Development Agency.

Mileszko, T. (18 czerwca 2020). „This War of Mine” wejdzie do kanonu lektur szkolnych. To pierwsza taka inicjatywa na świecie. Online: <http://www.komputerswiat.pl/gamezilla/aktualnosci/this-war-ofmine-wejdzie-do-kanonu-lektur-szkolnych-to-pierwsza-taka-inicjatywa-na/tzl2yzz>.

Okan, Z. (2003). Edutainment: is learning risk? British Journal of Educational Technology, 34(3), 255-264. Online: <http://web.csulb.edu/ arezaei/ ETEC444/discussion/edutainment.pdf>.

Peña-Miguel, N., Sedano, H. M. (2014). Educational Games for Learning. Universal Journal of Educational Research, 2(3), 230-238. Online: <https:// files.eric.ed.gov/fulltext/EJ1053979.pdf>.

Piechota, M. (2010). Edurozrywka - przyczynek do opisu zjawiska. W: M. Graszewicz, J. Jastrzębski (red.), Teorie komunikacji i mediów. Tom 2 (s. 231-239). Wrocław: Oficyna Wydawnicza „Atut” - Wrocławskie Wydawnictwo Oświatowe.

Quiroga, S. A. (2018). Race, "Battlefield 1" an the White Mythic Space of the First World War. Alicante Journal of English Studies, 31(1), 187-193. Online: <http://rua.ua.es/dspace/bitstream/10045/87178/6/RAEI_31_12. pdf $>$.

Quiroga, S. A., Filippaki, I. (2018). The Great War and the Use of Video Games as Historical and Educational Resources: A Conversation. Alicante Journal of English Studies, 31(1), 195-199. Online: <http://rua. ua.es/dspace/bitstream/10045/87228/6/RAEI_31_13.pdf>. 
Sieja, B. (6 listopada 2019). Gry komputerowe a propaganda. Twórcy manipulują historią od lat, ale... dlaczego tak się dzieje? Online: <http:// www.komputerswiat.pl/gamezilla/artykuly/gry-komputerowe-a-propaganda-tworcy-manipuluja-historia-od-lat-ale-dlaczego-tak-sie/ k62nhbh>.

Skibińska, M. (2010) Edutainment jako metoda edukacji przyszłości (teraźniejszości). Teraźniejszość - Człowiek - Edukacja, 13(2), 57-64. Online: <http://www.researchgate.net/publication/236209393_Edutainment_jako_metoda_edukacji_przyszlosci_terazniejszosci>.

Tang, S., Hanneghan, M., El Rhalibi, A. (2009). Introduction to GamesBased Learning. W: Th. Connolly, M. Stansfield, L. Boyle (red.), GamesBased Learning Advancements for Multi-Sensory Human Computer Interfaces: Techniques and Effective Practices (s. 1-13). Online: <https://www. igi-global.com/gateway/chapter/18785\#pnlRecommendationForm>.

Żmuda, M. (2016). „Valiant Hearts: The Great War” - gra wideo jako remediacja Wielkiej Wojny. W: A. Jamrozek-Sowa, Z. Ożóg, A. Wal (red.), I wojna światowa $w$ literaturze $i$ innych tekstach kultury. Reinterpretacje i dopełnienia (s. 596-607). Rzeszów: Wydawnictwo Uniwersytetu Rzeszowskiego.

\section{Ludografia}

Atari (1980). Red Baron [gra na automat]. Atari, USA.

Bytro Labs (2009). Supremacy 1914 [gra przeglądarkowa]. Bytro Labs, Niemcy.

Canadian War Museum (2014). Over the Top [gra przeglądarkowa]. Canadian War Museum, Kanada.

Digixart (2018). 11-11 Memories Retold [gra wieloplatformowa]. Bandai Namco, Japonia.

EA DICE (2016). Battlefield 1 [gra wieloplatformowa]. Electronic Arts, USA. The Farm 51 (2009). NecroVison [PC]. 5050 Games, Włochy. The Great War Dev Team (2013). Great War Mod [PC]. SEGA, USA. Hejka Studio (2019). Ku zwycięstwu [PC]. Hejka Studio, Polska. м2н/Blackmill Games (2015). Verdun [gra wieloplatformowa]. м2н/Blackmill Games, Holandia. 
MBD Limited (2018). Empire Soldiers: A Caribbean Story [Oculus VR]. MBD Limited, Wielka Brytania.

MBD Limited (2018). Empire Soldiers: A South Asian Story [Oculus VR]. MBD Limited, Wielka Brytania.

Rondomedia (2007). 1914 Shells of Fury [PC]. Strategy First, Kanada. Ubisoft Montpellier (2014). Valiant Hearts: The Great War [gra wieloplatformowa]. Ubisoft, Francja.

Thorium Games (2020). Within Whispers: The Fall [PC]. Thorium Games, Serbia.

\section{Źródta z YouTube}

The Great War (13 maja 2016). "Battlefield 1" Historical Trailer Analysis. The Great War Special. Online: <http://www.youtube.com/ watch?v=pvzEZ1Sq4tI\&t=3s>.

History Respawned (6 sierpnia 2014). History Respawned: "Valiant Hearts". Online: <http://www.youtube.com/watch?v=OzYQ8uAqAgo\&t=29s>. History Respawned (17 listopada 2016). History Respawned: "Battlefield 1". Online: <http://www.youtube.com/watch?v=WHXzMhY9- VU\& $=790 s>$.

Data dostępu do źródeł internetowych wykorzystanych w tekście: 25 czerwca 2020.

dr Łukasz Czajka - adiunkt w Instytucie Kulturoznawstwa UAM, autor książki Święta anarchia. Wprowadzenie do radykalnej hermeneutyki Johna D. Caputo (2014). Gtówne zainteresowania badawcze: kulturoznawcze badania nad wojną (zwłaszcza I wojną światową) oraz idee filozoficzne $w$ dzietach kultury popularnej.

Wielka Wojna jako temat gier wideo. Wyzwania dla edurozrywki w Valiant Hearts i Battlefield 1

Abstrakt: Głównym celem artykułu jest analiza wybranych gier wideo
poświęconych tematyce I wojny światowej. Aby dokonać pogłębionej
analizy porównawczej, skonfrontowano ze sobą dwie gry: Valiant Hearts
i Battlefield 1. Obie zostały porównane pod względem ich potencjalnego 
wykorzystania w edukacji rozrywkowej (edurozrywce). Zaprezentowane interpretacje służą także określeniu niektórych potencjalnych wyzwań, przed jakimi stają gry wideo aspirujące do miana narzędzi wspomagających tradycyjny proces edukacji o historii Wielkiej Wojny.

Słowa kluczowe: I wojna światowa, wojenne gry wideo, edurozrywka 
